\title{
Fluorine Flame Calorimetry III. The Heat of Formation of Chlorine Trifluoride at 298.15 K*
}

\author{
R. C. King** and G. T. Armstrong \\ Institute for Materials Research, National Bureau of Standards, Washington, D.C. 20234
}

(July 6, 1970)

\begin{abstract}
The standard heat of formation of chlorine trifluoride (gas) at $298.15 \mathrm{~K}$ has been determined to be $-164.65 \mathrm{~kJ} \mathrm{~mol}^{-1}\left(-39.35 \mathrm{kcal} \mathrm{mol}^{-1}\right)$ with an overall experimental uncertainty of $5.14 \mathrm{~kJ} \mathrm{~mol}^{-1}$ (1.23 kcal mol-1). This value is derived from the enthalpies of the following reactions which were measured directly in a flame calorimeter operated at 1 atm pressure and $303.5 \mathrm{~K}$, together with data from previous investigations.

$$
\begin{gathered}
\mathrm{ClF}_{3}(\mathrm{~g})+2 \mathrm{H}_{2}(\mathrm{~g})+100 \mathrm{H}_{2} \mathrm{O}(\mathrm{l}) \rightarrow\left[\mathrm{HCl} \cdot 3 \mathrm{HF} \cdot 100 \mathrm{H}_{2} \mathrm{O}\right](\mathrm{l}) \\
(\mathrm{l} / 2) \mathrm{Cl}_{2}(\mathrm{~g})+1 / 2 \mathrm{H}_{2}(\mathrm{~g})+\left[3 \mathrm{HF} \cdot 100 \mathrm{H}_{2} \mathrm{O}\right](\mathrm{l}) \rightarrow\left[\mathrm{HCl} \cdot 3 \mathrm{HF} \cdot 100 \mathrm{H}_{2} \mathrm{O}\right](\mathrm{l})
\end{gathered}
$$

The enthalpy of formation of $\left[\mathrm{HCl} \cdot 100 \mathrm{H}_{2} \mathrm{O}\right](\mathrm{l})$ was also measured. The average $\mathrm{Cl}-\mathrm{F}$ bond energy in chlorine trifluoride is calculated to be $160.1 \mathrm{~kJ} \mathrm{~mol}^{-1}\left(38.26 \mathrm{kcal} \mathrm{mol}^{-1}\right)$.

Key words: Bond energy $(\mathrm{Cl}-\mathrm{F})$; chlorine reaction with hydrogen; chlorine trifluoride, heat of formation; flame calorimetry; flow calorimetry; fluorine compounds; heat of formation; heat of reaction; hydrogen chloride (aqueous), heat of formation; mixed acids: $(\mathrm{HCl}+3 \mathrm{HF})_{\text {aq }}$, heat of formation; reaction calorimetry; reaction with hydrogen.
\end{abstract}

\section{Introduction}

Chlorine trifluoride is a vigorous fluorinating agent which combines spontaneously with many other compounds and elements. This fluorine-containing oxidizer is easily liquefied, and for this reason, has some applications different from those of other fluorine compounds. However, as with the other fluorinecontaining oxidizers, the special applications of chlorine trifluoride, such as its use in rocket propulsion, require accurate thermochemical data.

In the past, there have been few original studies on the heat of formation of chlorine trifluoride. Possibly this is caused by its extreme reactivity, which is the greatest obstacle to a definitive study of its heat of formation. Schmitz and Schumacher $[1]^{1}$ and Schäfer and Wicke [2] determined equilibrium constants at various temperatures for the reaction, $\mathrm{ClF}_{3}(\mathrm{~g}) \rightarrow$ $\mathrm{ClF}(\mathrm{g})+\mathrm{F}_{2}(\mathrm{~g})$. Von $\mathrm{W}$ artenberg and Riteris [3] and Schmitz and Schumacher [4] measured the heat of the reaction, $\mathrm{ClF}_{3}(\mathrm{~g})+3 \mathrm{NaCl}(\mathrm{c}) \rightarrow 3 \mathrm{NaF}(\mathrm{c})+2 \mathrm{Cl}_{2}(\mathrm{~g})$. These studies have been evaluated repeatedly in different reviews for the purpose of selecting a "best" value for $\Delta H_{f}\left(\mathrm{ClF}_{3}\right)$. The values currently given are -38.0 [5]

* Research sponsored by the Air Force Office of Scientific Research, Office of Aerospace Research, United States Air Force, under AFOSR Contract No. ISSA-69-0001.

**Present address: Chemistry Department, York College of the City University of New York, N.Y. 11365.

'Figures in brackets indicate the literature references at the end of this paper. and $-38.869 \pm 1.0[6] \mathrm{kcal} \mathrm{mol}^{-1}$. It is difficult to analyze the reasons for the relatively small uncertanties in these data and no further attempt will be made at this time. The principal reason for undertaking this work was that evidence from some test rocket propulsion studies, and some unpublished thermochemical information suggested that the enthalpy of formation might be in the range of -26 kcal mol-1, a difference of over $10 \mathrm{kcal} \mathrm{mol}^{-1}$ from the published values.

In the present study, the heat of formation of chlorine trifluoride is determined by fluorine flame calorimetry, a technique which is very different from techniques used in earlier studies on this substance. The advantages of this technique are discussed in detail in recent reports on the heat of formation of other fluorine compounds studied in this laboratory [7, 8]. The determination of the heat of formation of chlorine trifluoride by direct combination of the elements is complicated by the formation of mixed halides. As an alternative, the reaction of chlorine trifluoride with hydrogen followed by solution of the products to form an aqueous mixture of hydrofluoric and hydrochloric acids was selected for this study.

The heat of formation of chlorine trifluoride, the enthalpy of reaction (1), is derived from reactions (2), (3), (4), and (5). (Reaction $1=$ Reaction $(3+4-5-2)$.) The heats of the $\mathrm{ClF}_{3}-\mathrm{H}_{2}-\mathrm{H}_{2} \mathrm{O}$, and $\mathrm{Cl}_{2}-\mathrm{H}_{2}=\mathrm{HF}(\mathrm{aq})$, 
reactions, (2) and (3), were measured directly in this study. The heat of the $\mathrm{F}_{2}-\mathrm{H}_{2}-\mathrm{H}_{2} \mathrm{O}$ reaction (4) was studied earlier [8], and a necessary dilution energy, the enthalpy of reaction (5), obtained from the literature [5].

The calorimeter was calibrated with the oxygenhydrogen reaction (6).

$$
\begin{gathered}
1 / 2 \mathrm{Cl}_{2}(\mathrm{~g})+3 / 2 \mathrm{~F}_{2}(\mathrm{~g}) \rightarrow \mathrm{ClF}_{3}(\mathrm{~g}) \\
\mathrm{ClF}_{3}(\mathrm{~g})+2 \mathrm{H}_{2}(\mathrm{~g})+100 \mathrm{H}_{2} \mathrm{O}(\mathrm{l}) \rightarrow \\
{\left[\mathrm{HCl} \cdot 3 \mathrm{HF} \cdot 100 \mathrm{H}_{2} \mathrm{O}\right](\mathrm{l})} \\
1 / 2 \mathrm{Cl}_{2}(\mathrm{~g})+1 / 2 \mathrm{H}_{2}(\mathrm{~g})+\left[3 \mathrm{HF} \cdot 100 \mathrm{H}_{2} \mathrm{O}\right](\mathrm{l}) \rightarrow \\
{\left[\mathrm{HCl} \cdot 3 \mathrm{HF} \cdot 100 \mathrm{H}_{2} \mathrm{O}\right](\mathrm{l})} \\
3 / 2 \mathrm{~F}_{2}(\mathrm{~g})+3 / 2 \mathrm{H}_{2}(\mathrm{~g})+150 \mathrm{H}_{2} \mathrm{O}(\mathrm{l}) \rightarrow\left[3 \mathrm{HF} \cdot 150 \mathrm{H}_{2} \mathrm{O}\right](\mathrm{l}) \\
{\left[3 \mathrm{HF} \cdot 100 \mathrm{H}_{2} \mathrm{O}\right](\mathrm{l})+50 \mathrm{H}_{2} \mathrm{O}(\mathrm{l}) \rightarrow\left[3 \mathrm{HF} \cdot 150 \mathrm{H}_{2} \mathrm{O}\right](\mathrm{l})} \\
1 / 2 \mathrm{O}_{2}(\mathrm{~g})+\mathrm{H}_{2}(\mathrm{~g}) \rightarrow \mathrm{H}_{2} \mathrm{O}(\mathrm{l}) \\
1 / 2 \mathrm{Cl}_{2}(\mathrm{~g})+1 / 2 \mathrm{H}_{2}(\mathrm{~g})+100 \mathrm{H}_{2} \mathrm{O}(\mathrm{l}) \rightarrow \\
{\left[\mathrm{HCl} \cdot 100 \mathrm{H}_{2} \mathrm{O}\right](\mathrm{l})}
\end{gathered}
$$

Reaction (7) is closely related to reaction (3). Because accurate data for reaction (7) are available in the literature, a measurement of the enthalpy gives a way of checking the overall validity of the procedures used in this study.

\section{Experimental Apparatus and Procedures}

\subsection{The Samples}

Commercially available samples of hydrogen, oxygen, chlorine, and chlorine trifluoride were used. The oxygen and hydrogen samples were of high purity and are the same grades used for earlier flame calorimetric studies [8]. The mass fraction of $\mathrm{O}_{2}$ in the oxygen sample was 0.99987 and the mole fraction of $\mathrm{H}_{2}$ in the hydrogen sample was 0.999 . The hydrogen was used directly from the source cylinder. Each of the oxidizer gases was used from small weighable containers with a volume of about $250 \mathrm{~cm}^{3}[7,8]$. The containers were chilled with solid carbon dioxide to condense the chlorine and chlorine trifluoride into them.

Chlorine-The chlorine sample was a high purity grade and was not subjected to any additional purification. The chlorine was transferred to the weighable container and was contained as a liquid under its vapor pressure of $5.8 \mathrm{~atm}$ at $25^{\circ} \mathrm{C}$. The purity was checked using the mercury-absorption method $[8,9,10]$, and subsequent analysis of the residual gas by mass spectrometry. In carrying out the usual procedure some

\begin{tabular}{|c|c|c|}
\hline \multirow{3}{*}{ Constituent } & \multicolumn{2}{|c|}{ Sample } \\
\hline & $\begin{array}{c}\mathrm{ClF}_{3} \\
\text { (gas phase) }\end{array}$ & $\mathrm{Cl}_{2}$ \\
\hline & \multicolumn{2}{|c|}{ Weight percent } \\
\hline $\mathrm{CIF}_{3}$ & 99.82 & - \\
\hline $\mathrm{Cl}_{2}$ & - & 99.93 \\
\hline $\mathrm{F}_{2}$ & - & - \\
\hline $\mathrm{O}_{2}$ & 0.15 & 0.02 \\
\hline $\mathrm{N}_{2}$ & .01 & .05 \\
\hline $\mathrm{Ar}$ & $*$ & $*$ \\
\hline $\mathrm{CO}_{2}$ & 0.01 & $*$ \\
\hline $\mathrm{CF}_{4}$ & * & - \\
\hline $\mathrm{C}_{2} \mathrm{~F}_{6}$ & * & - \\
\hline $\mathrm{C}_{3} \mathrm{~F}_{8}$ & $*$ & - \\
\hline $\mathrm{C}_{4} \mathrm{~F}_{8}$ & $*$ & - \\
\hline $\mathrm{SO}_{2} \mathrm{~F}_{2}$ & - & - \\
\hline $\mathrm{SiF}_{4}$ & - & - \\
\hline
\end{tabular}
of the sample from the weighable container was transferred to an evacuated Pyrex glass bulb containing mercury. The bulb was immersed in hot water to initiate the reaction. The composition of the chlorine as found by this analysis is given in table 1 .

Chlorine trifluoride-The chlorine trifluoride was contained as a liquid under its vapor pressure of 1.47
TABLE 1. Compositions of the chlorine and chlorine trifluoride samples

atm at $25{ }^{\circ} \mathrm{C}$. The principal impurities in the chlorine trifluoride sample were hydrogen fluoride, oxygen, nitrogen, and carbon dioxide. In the process of transfer to the weighable container the gas was passed over activated sodium fluoride for removal of the hydrogen fluoride.

After removal of the hydrogen fluoride, the remaining impurities are more volatile than the chlorine trifluoride. It is possible that the sample becomes purer in chlorine trifluoride as a series of experiments is completed. To check this point, duplicate analyses were performed on the sample at different times. The results showed the sample to contain 0.47 and 0.45 mole percent impurities, and give no evidence of such a fractionation.

For a quantitative analysis of the sample, as with the chlorine, the chlorine trifluoride was reacted with mercury and the residual gas was analyzed by mass spectrometry. Chlorine trifluoride reacts vigorously with mercury. For these analyses the mercury and container were conditioned with chlorine trifluoride and then reevacuated prior to filling to the final pressure of $1 \mathrm{~atm}$. The results of the analyses are given in table 1 .

Limitations of the absorption method have been discussed [8]. Possible impurities that would also react with the mercury under the conditions of the test are $\mathrm{Cl}_{2}, \mathrm{ClF}$, and $\mathrm{Cl}-\mathrm{O}-\mathrm{F}$ compounds. Oxygen liberated by reactions of impurities might affect the observed amount of free oxygen. The possible errors due to lack of information about such impurities are taken into account in the discussion of errors.

\subsection{The Reaction Vessel and Flow System}

The reaction vessel is illustrated in figure 1. It consists of a heat exchanger, combustion chamber, two solution vessels, various connecting tubes; and smaller parts. See section 2.3 for a brief description of its use. It is similar to the one used for the study of oxygen difluoride which has already been described [8]. The 


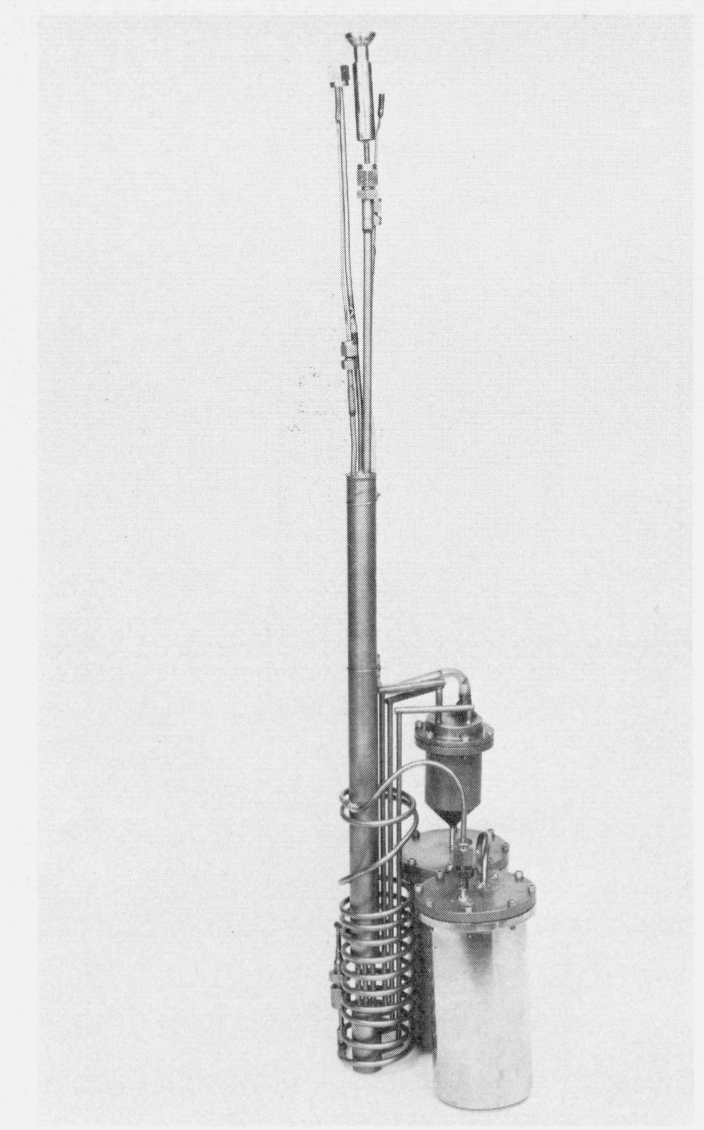

Figure 1. Assembled reaction vessel.

The principal change from the vessel previously described is the substitution of the secondary solution vessel in the foreground for a smaller one previously used.

main modification is the use of a secondary solution vessel of a volume equal to that of the primary solution vessel in place of a smaller secondary solution vessel. This change was made because of significant losses of the mixed acids when the smaller secondary vessel was used. The undersides of the Monel $^{2}$ lids to the solution vessels were coated with polytetrafluoroethylene (PTFE). For an experiment each solution vessel contained $100 \mathrm{~cm}^{3}$ of water.

In addition to its greater volatility from the aqueous solutions the mixture of hydrogen chloride and hydrogen fluoride formed in the chlorine trifluoride-hydrogen reaction was observed to be extremely corrosive in the combustion chamber. To minimize loss of the acid by corrosion, a removable platinum liner $(0.05 \mathrm{~mm}$ thick) was placed in the lower part of the combustion chamber. For the chlorine-hydrogen reactions, a platinum liner was also placed on the underside of the lid to the combustion chamber. Platinum in this position was found to be very unsuitable for the chlorine trifluoride experiments. In preliminary experiments with chlorine trifluoride, a liner on the lid vaporized to

${ }^{2}$ Certain commercial products are identified in this paper in order t 1 . specify adequately the experimental procedure. In no case does such identification imply recommendation or endorsement by the National Bureau of Standards, nor does it imply that the products identified are necessarily the best for the purpose. a certain extent, leaving a soot-like deposit on the walls of the combustion chamber. A spectrochemical analysis of this deposit revealed it to be platinum.

The overall design of the flow system is similar to that used earlier. The major modification was introduced in the oxidizer flow line. A commercially available mass flowmeter operating on a thermal conductivity principle was inserted in the oxidizer flow line. This modification is shown in figure 2. However, because of the extreme reactivity of chlorine trifluoride, the Pyrex flowmeter was replaced with a stand-in Monel tube for the chlorine trifluoride experiments. The Pyrex flowmeter was used satisfactorily for the oxygen and the chlorine reactions and was found very useful for monitoring the $\mathrm{O}_{2}-\mathrm{H}_{2}$ and $\mathrm{Cl}_{2}-\mathrm{H}_{2}$ flames.

\subsection{The Calorimetric Procedures and Calculations}

The calorimeter and its operation were the same as used in an earlier study [8]. The temperature of the jacket water was controlled at $32{ }^{\circ} \mathrm{C}$. The reactions were initiated with a high voltage spark.

The experiments were conducted using procedures similar to those developed for the oxygen difluoride study. The oxidizer was introduced into a flowing atmosphere of excess hydrogen and reacted in a steady flame. The products of combustion passed into the aqueous phase in the primary solution vessel, immediately below, where most of the products were absorbed. The small amount that passed beyond the primary solution vessel was absorbed in the secondary solution vessel. The reaction periods ranged from approximately 10 to approximately 20 minutes.

Initially the low vapor pressure of chlorine trifluoride caused some difficulty in maintaining the $\mathrm{ClF}_{3}-\mathrm{H}_{2}$ flame. As the $\mathrm{ClF}_{3}$ was released from the bulb, the cooling effect of the vaporization caused a lowering of the vapor pressure and as a result, the flame was sometimes extinguished. This problem was solved by immersing the sample bulb in a water bath at $30^{\circ} \mathrm{C}$.

The calculations of the temperature data were made with a FORTRAN computer program written by Shomate [11]. The quantities obtained from the program include $\Delta t_{c}, \Delta t$ (corr), and $t(\mathrm{av})$. See section 4 for definitions.

The heat capacity data used for the calculations are given in table la. For this paper the calorie is taken as $\mathrm{l} \mathrm{cal}=4.184 \mathrm{~J}$. The atomic weights are taken from the 1961 table of Atomic Weights based on carbon 12 [12]. The heats of vaporization of water are 2439 and 2428 $\mathrm{J} \mathrm{g}^{-1}$ at 298.15 and $303.15 \mathrm{~K}$, respectively [13].

TABLE 1a. Heat capacity data

\begin{tabular}{l|c|c}
\hline \hline \multicolumn{1}{c|}{ Substance } & $\begin{array}{c}C_{p} 298.15 \\
\mathrm{~J} \mathrm{~mol} \mathrm{~mol}^{-1}\end{array}$ & Reference \\
\hline $\mathrm{ClF}_{3}(\mathrm{~g})$ & 63.85 & {$[5]$} \\
$\mathrm{O}_{2}(\mathrm{~g})$ & 29.36 & {$[5]$} \\
$\mathrm{Cl}_{2}(\mathrm{~g})$ & 33.91 & {$[5]$} \\
$\mathrm{H}_{2}(\mathrm{~g})$ & 28.82 & {$[5]$} \\
$\mathrm{H}_{2} \mathrm{O}(\mathrm{l})$ & 75.291 & {$[5]$} \\
$\mathrm{HCl}\left(100 \mathrm{H}_{2} \mathrm{O}\right)(\mathrm{l})$ & -116.3 & {$[16]$} \\
\hline
\end{tabular}




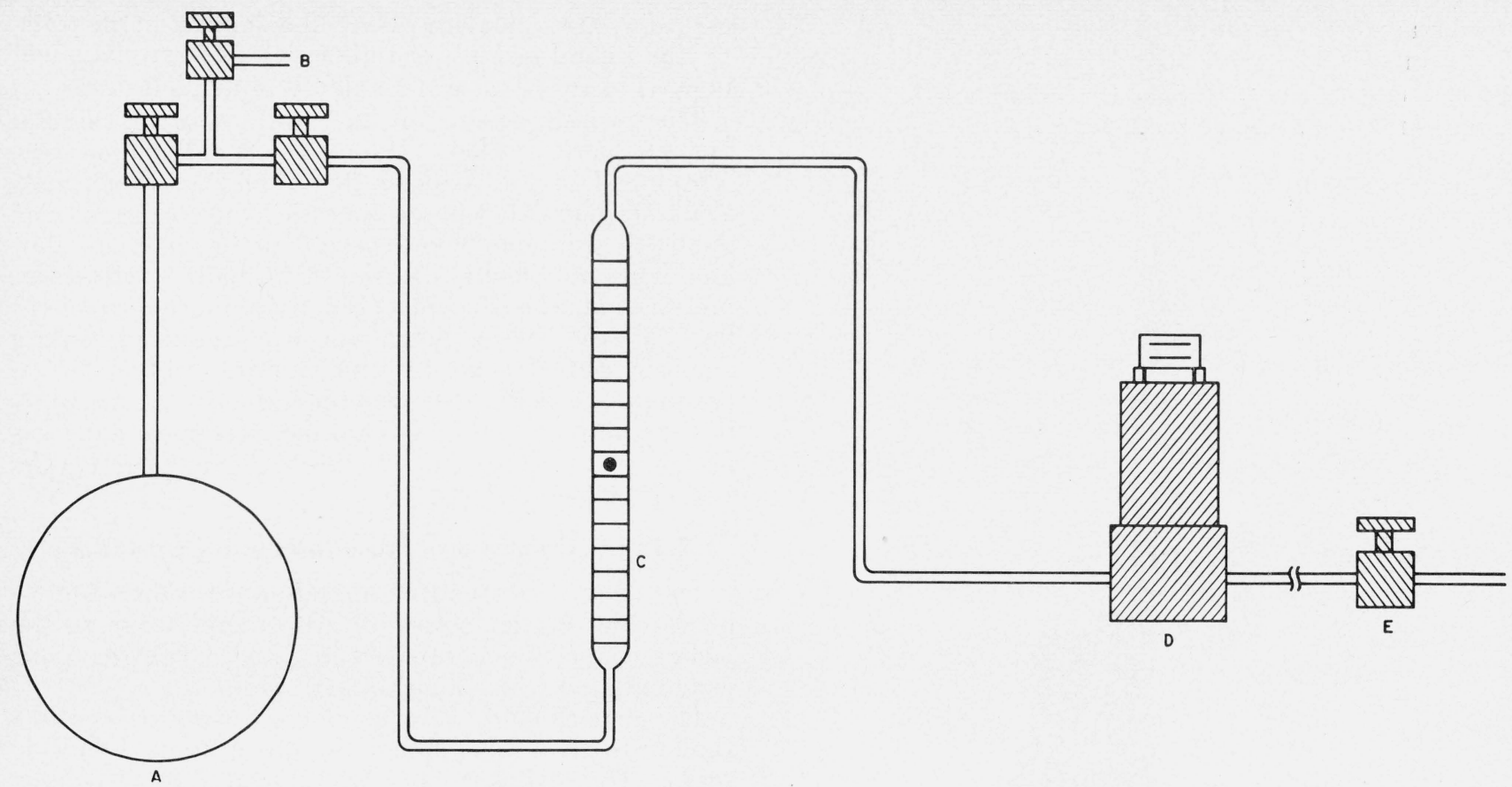

FIGURE 2. The oxidizer flow line.

A, Sample container; B, Helium source; C, Pyrex flowmeter; D, Mass-flowmeter transducer; E, Valve opening to the reaction vessel.

\subsection{The Removal of Water from the Reaction Vessel}

The continual flow of hydrogen through the reaction vessel causes a removal of water vapor from the inside to the outside of the calorimeter. To reduce errors in the corrected temperature rise the net water removal was minimized by adding a similar amount of water as vapor to the reaction vessel. To do this the hydrogen was passed through saturators placed just before the calorimeter [8]. The net thermal effect of evaporation is observed as a part of the temperature drift rate of the calorimeter in the initial and final periods. As a check on the magnitude of this effect the amounts of water carried into and removed from the reaction vessel were measured and are compared in table 2. Except for the $\mathrm{Cl}_{2}-\mathrm{H}_{2}-\mathrm{H}_{2} \mathrm{O}$ reaction, the compensation is fairly close, the net increase in the reaction vessel ranging from -0.13 to $+0.10 \mathrm{~g}$. There is a consistently larger increase in the water content of the reaction vessel for the $\mathrm{Cl}_{2}-\mathrm{H}_{2}-\mathrm{H}_{2} \mathrm{O}$ reaction, the net increase ranging from 0.27 to $0.60 \mathrm{~g}$. The explanation for this larger increase is unknown, but may be due to a pronounced lowering of the vapor pressure of water by $\mathrm{HCl}$ alone in contrast to its behavior when mixed with HF. The corrected temperature rises are expected to be accurate, nevertheless, because the increase is presumed to occur over the 60-70 min experimental period and to be uniform during the drift periods. During the reaction period a certain fraction of the gases entering the calorimeter does not leave the calorimeter. The thermal effect of condensation of water from this amount of gas is applied as a correction (see $q$ (vap), sec. 4.1$)$.
TABLE 2. Water changes in reaction vessel

\begin{tabular}{|c|c|c|c|}
\hline $\begin{array}{c}\text { Expt. } \\
\text { No. }\end{array}$ & $\begin{array}{c}\text { Water } \\
\text { removed } \\
g\end{array}$ & $\begin{array}{c}\text { Water } \\
\text { carried in } \\
g\end{array}$ & $\begin{array}{c}\text { Net } \\
\text { increase } \\
g\end{array}$ \\
\hline \multicolumn{4}{|c|}{ Oxygen-hydrogen reaction } \\
\hline $\begin{array}{l}1 \\
2 \\
3 \\
4 \\
5 \\
6\end{array}$ & $\begin{array}{r}0.7634 \\
.8477 \\
1.0371 \\
1.0463 \\
0.7795 \\
.7060\end{array}$ & $\begin{array}{r}0.8615 \\
.8574 \\
1.0635 \\
0.9446 \\
.8828 \\
.7508\end{array}$ & $\begin{array}{r}0.0981 \\
.0097 \\
.0264 \\
-.1017 \\
.1033 \\
.0448\end{array}$ \\
\hline \multicolumn{4}{|c|}{ Chlorine trifluoride-hydrogen-water-reaction } \\
\hline $\begin{array}{l}1 \\
2 \\
3 \\
4 \\
5 \\
6\end{array}$ & $\begin{array}{r}0.5959 \\
.7055 \\
.5679 \\
.6038 \\
.7337 \\
.6998\end{array}$ & $\begin{array}{r}0.5781 \\
.7589 \\
.6636 \\
.6484 \\
.7408 \\
.7184\end{array}$ & $\begin{array}{r}-10.0178 \\
.0534 \\
.0957 \\
.0446 \\
.0071 \\
.0186\end{array}$ \\
\hline \multicolumn{4}{|c|}{ Chlorine-hydrogen-water reaction } \\
\hline $\begin{array}{l}1 \\
2 \\
3 \\
4\end{array}$ & $\begin{array}{r}0.3229 \\
.3016 \\
.5554 \\
.8892\end{array}$ & $\begin{array}{r}0.6809 \\
.5931 \\
.8235 \\
1.4887\end{array}$ & $\begin{array}{r}0.3580 \\
.2915 \\
.2681 \\
.5995\end{array}$ \\
\hline \multicolumn{4}{|c|}{ Chlorine-hydrogen- $\mathrm{HF}_{\mathrm{aq}}$ reaction } \\
\hline $\begin{array}{l}1 \\
2 \\
3 \\
4 \\
5\end{array}$ & $\begin{array}{r}0.8163 \\
.9960 \\
\ldots \ldots \ldots \ldots \\
.6777 \\
.8135\end{array}$ & $\begin{array}{r}0.7222 \\
.8689 \\
.8010 \\
.6136 \\
.7377\end{array}$ & $\begin{array}{c}-0.0941 \\
-.1271 \\
\ldots \ldots \ldots \ldots \\
-.0641 \\
-.0758\end{array}$ \\
\hline
\end{tabular}


The analysis data for the $\mathrm{ClF}_{3}-\mathrm{H}_{2}-\mathrm{H}_{2} \mathrm{O}$ reaction are given in table $3 . n_{\mathrm{H}^{+}}$(obs) and $n_{\mathrm{H}^{+}}$(calc) are the observed and calculated amounts of acid respectively. The completeness of the reaction is shown by

$$
\frac{n_{\mathrm{H}^{+}}(\mathrm{obs})}{n_{\mathrm{H}^{+}}(\text {calc })} \text {. }
$$

The generally low values of this ratio can be explained by the extremely reactive character of the acid mixture, $\mathrm{HCl} \cdot 3 \mathrm{HF}$. No explanation is offered for the erratic but favorable value for experiment 5 . It is immaterial whether the chlorine trifluoride sample reacts directly with the metal or whether it reacts with hydrogen to completion inside the reaction vessel and the corrosion results from the reaction of the product acid with the metal, the results will show up as a deficiency of total acidity of the solution. Therefore, $n_{\mathrm{ClF}_{3}}$ (corros) is derived from the difference between $n_{\mathrm{H}^{+}}$(obs) and
$n_{\mathrm{H}^{+}}$(calc). This neglects the possibility that some $\mathrm{HCl}-\mathrm{HF}$ or unreacted $\mathrm{ClF}_{3}$ may have escaped from the reaction vessels.

$$
\text { The } \frac{n_{\mathrm{H}^{+}}(\mathrm{obs})}{n_{\mathrm{H}^{+}}(\text {calc })}
$$

values shown here resemble those for the $\mathrm{F}_{2}-\mathrm{H}_{2}-\mathrm{H}_{2} \mathrm{O}$ reaction which were reported earlier [8]. After the $\mathrm{ClF}_{3}-\mathrm{H}_{2}-\mathrm{H}_{2} \mathrm{O}$ reaction, the combustion chamber of the reaction vessel does show a considerable amount of corrosion, especially on the burner tip. A yellowishgreen discoloration appears on the walls. In comparison with the noble metals, Monel still appears to be the most suitable material for construction of reaction containers for chlorine trifluoride. Possibly the recovery of the acid in these experiments could be improved by using a larger reaction vessel and a large amount of excess hydrogen during the reaction.

\begin{tabular}{|c|c|c|c|c|c|c|}
\hline Expt. No. & 1 & $2^{\prime \prime}$ & 3 & 4 & 5 & 6 \\
\hline 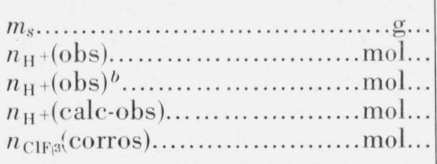 & $\begin{array}{l}5.5074 \\
0.23262 \\
.23786 \\
.00524 \\
.001310\end{array}$ & $\begin{array}{l}5.3577 \\
0.22461 \\
.23140 \\
.00679 \\
.001698\end{array}$ & $\begin{array}{l}5.1142 \\
0.21545 \\
.22088 \\
.00543 \\
.001358\end{array}$ & $\begin{array}{l}4.4999 \\
0.19024 \\
.19435 \\
.00411 \\
.001028\end{array}$ & $\begin{array}{l}5.2142 \\
0.22349 \\
.22520 \\
.00171 \\
.000428\end{array}$ & $\begin{array}{l}4.9769 \\
0.21035 \\
.21495 \\
.00460 \\
.001150\end{array}$ \\
\hline$n_{\mathrm{H}^{+}}($obs $) / n_{\mathrm{H}^{+}}($calc $) \ldots \ldots \ldots \ldots \ldots \ldots \ldots \ldots \ldots$ & .9780 & .9707 & .9754 & .9789 & .9924 & .9786 \\
\hline 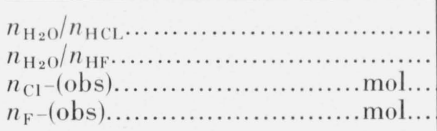 & $\begin{array}{l}96 \\
32\end{array}$ & $\begin{array}{l}99 \\
33\end{array}$ & $\begin{array}{r}102 \\
34\end{array}$ & $\begin{array}{c}117 \\
39 \\
\cdots \cdots \cdots \\
\cdots \cdots\end{array}$ & $\begin{array}{r}99 \\
33 \\
0.05579 \\
.16716\end{array}$ & $\begin{array}{r}105 \\
35\end{array}$ \\
\hline
\end{tabular}

TABLE 3. Completeness of the $\mathrm{ClF}_{3}-\mathrm{H}_{2}-\mathrm{H}_{2} \mathrm{O}$ reaction

${ }^{a}$ Not used in the final results.

${ }^{b}$ The molecular weight of $\mathrm{ClF}_{3}$ is 92.4482 . The sample purity was 0.9982 . The value of $n_{\mathrm{H}+}\left(\right.$ calc) is given by $m_{s} \times 4 \times 0.9982 / 92.4482$.

\section{The Completeness of the Reactions}

The reactive nature of the reactants and products in the systems studied makes it difficult to determine the amounts of the desired reactions taking place. Yet this aspect of the study is critically important to the accuracy of the heats of reaction.

Our usual procedure of comparing the measured amount of the oxidizer introduced with the measured amount of the acid formed was used. Any deviation from a mass balance determined in this way was assumed to be caused by the corrosion reaction of the oxidizer with the reaction vessel. A correction, $q$ (corros), is applied to the observed heat effect for this amount of corrosion.

The amount of chlorine trifluoride sample introduced into the reaction was determined by weighing the sample bulb to $0.1 \mathrm{mg}$ before and after each experiment. The amount of chlorine trifluoride introduced was calculated using the analysis of the sample given in table 1. All chlorine trifluoride introduced was assumed to have reacted and the amount was used to calculate the anticipated amount of $\mathrm{H}^{+}$, which we call $n_{\mathrm{H}}+$ (calc). The total amount of acid formed was determined in the Analytical Chemistry Division at the National Bureau of Standards. To verify the results for the $\mathrm{H}^{+}$, analysis for the $\mathrm{Cl}^{-}$and $\mathrm{F}^{-}$was performed for experiment 5 . The sum of these is 0.2 percent less than the total hydrogen ion observed. In the absence of any obvious source of this difference it may be taken as due to a small systematic difference between the methods of analysis. The amounts of $\mathrm{H}^{+}$and $\mathrm{Cl}^{-}$were measured using two independent coulometric methods. The $\mathrm{F}^{-}$ determination was performed by potentiometric titration with standard $\mathrm{LaCl}_{3}$ solution, using a fluorideactivity-indicator electrode.

From the data shown in table 3 , a value of 0.3337 is derived for $\frac{n_{\mathrm{Cl}^{-}}}{n_{\mathrm{F}^{-}}}$, which is not significantly different from the theoretical ratio of 0.3333 . This suggests that any undetected impurities in the chlorine trifluoride sample are present in very small amounts or have the same $\mathrm{Cl}: \mathrm{F}$ ratio.

The analysis data for the $\mathrm{Cl}_{2}-\mathrm{H}_{2}-\mathrm{H}_{2} \mathrm{O}$ and $\mathrm{Cl}_{2}-\mathrm{H}_{2}-\mathrm{HF}_{\mathrm{aq}}$ reactions are given in table 4 . The $n_{\mathrm{H}}+(\mathrm{obs})$ excluding the $\mathrm{H}^{+}$introduced as $\mathrm{HF}_{\mathrm{aq}}$ is shown as $n_{\mathrm{HCl}}(\mathrm{obs})$ for each experiment. The value of $n_{\mathrm{Cl}}-$ (obs) is given for a typical experiment. Compared 
TABLE 4. Completeness of the $\mathrm{Cl}_{2}-\mathrm{H}_{2}-\mathrm{H}_{2} \mathrm{O}$ and $\mathrm{Cl}_{2}-\mathrm{H}_{2}-\mathrm{HF}_{\mathrm{aq}}$ reactions

\begin{tabular}{|c|c|c|c|c|c|c|c|c|c|}
\hline \multirow{2}{*}{ Expt. No. } & \multicolumn{5}{|c|}{$\mathrm{Cl}_{2}-\mathrm{H}_{2}-\mathrm{H}_{2} \mathrm{O}$} & \multicolumn{4}{|c|}{$\mathrm{Cl}_{2}-\mathrm{H}_{2}-\mathrm{HF}_{\mathrm{aq}}$} \\
\hline & 1 & 2 & 3 & 4 & 1 & 2 & 3 & 5 & 6 \\
\hline 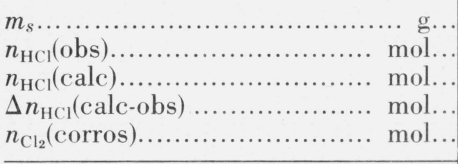 & $\begin{array}{l}9.6607 \\
0.26976 \\
.27230 \\
.00254 \\
.001270\end{array}$ & $\begin{array}{l}6.7661 \\
0.19053 \\
.19070 \\
.00017 \\
.000085\end{array}$ & $\begin{array}{l}6.6417 \\
0.18702 \\
.18720 \\
.00018 \\
.000090\end{array}$ & $\begin{array}{l}7.6865 \\
0.21625 \\
.21664 \\
.00039 \\
.000195\end{array}$ & $\begin{array}{l}2.1408 \\
0.06019 \\
.06034 \\
.00015 \\
.000075\end{array}$ & $\begin{array}{l}2.5748 \\
0.07250 \\
.07258 \\
.00008 \\
.000040\end{array}$ & $\begin{array}{l}4.4517 \\
0.12526 \\
.12548 \\
.00022 \\
.000110\end{array}$ & $\begin{array}{l}2.2925 \\
0.06416 \\
.06466 \\
.00050 \\
.000250\end{array}$ & $\begin{array}{c}1.5869 \\
0.04457 \\
.04444 \\
-.00013 \\
\ldots . . .6 . . .\end{array}$ \\
\hline 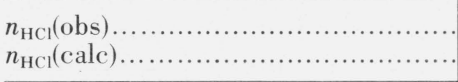 & .9907 & .9990 & .9990 & .9982 & .9975 & .9989 & .9982 & .9923 & 1.0029 \\
\hline 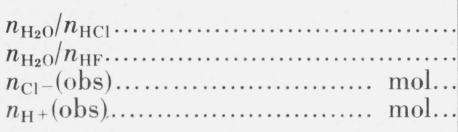 & 20 & 29 & $\begin{array}{c}30 \\
\ldots \ldots \ldots \ldots \\
0.18715 \\
.18702\end{array}$ & 26 & $\begin{array}{l}90 \\
33\end{array}$ & $\begin{array}{l}74 \\
32\end{array}$ & $\begin{array}{c}43 \\
32 \\
\ldots \ldots \ldots\end{array}$ & $\begin{array}{l}87 \\
32\end{array}$ & $\begin{array}{r}121 \\
32\end{array}$ \\
\hline
\end{tabular}

to the $\mathrm{ClF}_{3}-\mathrm{H}_{2}-\mathrm{H}_{2} \mathrm{O}$ reactions, the recovery of the acid is improved considerably for the chlorine-hydrogen systems. This improved recovery of the acid probably is accounted for by the observations that (1) $\mathrm{HCl}$ alone is less reactive towards Monel than the $\mathrm{HCl}-3 \mathrm{HF}$ mixture and (2) lining the combustion chamber with platinum foil shields the monel from the HCl.

The $\frac{\left.n_{\mathrm{Cl}^{-}}-\text {obs }\right)}{n_{\mathrm{H}}+}$ value is 1.0007 , slightly higher than the expected value of 1.0000 . This trend was observed also for some preliminary experiments, and if real may indicate that some loss in acid is due to corrosion in which $\mathrm{H}^{+}$reacted.

Values of $n_{\mathrm{H}_{2} \mathrm{O}} / n_{\mathrm{HCl}}$ and $n_{\mathrm{H}_{2} \mathrm{O}} / n_{\mathrm{HF}}$ are shown in tables 3 and 4 and are used later to apply a heat-of-dilution correction to the final heats of reaction. The $\mathrm{HF}_{\mathrm{aq}}$ solutions were prepared and analyzed before the experiments. The desired amount was weighed into the solution vessel before assembly of the reaction vessel. Therefore, no subsequent analysis for the $\mathrm{HF}$ was required.

The amount of the $\mathrm{O}_{2}-\mathrm{H}_{2}$ reaction is based on the mass of oxygen reacted. For calibration purposes Rossini [14] recommends that the amount of reaction be based on the amount of water formed. In our earlier study, we measured the amount of water formed in a dry reaction vessel and compared this with the amount of oxygen reacted. The observed versus the expected amounts of water were in close agreement in that test. It is desirable to perform the "reaction" calibration using the same procedures used for the reaction involving the fluorine oxidizer. Because water is contained in the solution vessels, it is not convenient to collect the water formed in the $\mathrm{O}_{2}-\mathrm{H}_{2}$ reactions. Under these circumstances, we believe that the best accuracy is obtained by basing the amount of reaction on the amount of oxygen introduced into the reaction.

\section{The Heat Measurements}

\subsection{The Calibration of the Calorimeter}

\section{The $\mathrm{O}_{2}-\mathrm{H}_{2}$ Reaction}

The calorimeter was calibrated with the oxygenhydrogen reaction using most of Rossini's recom- mended procedures [14]. The data for these experiments are given in table 5 . The amount of oxygen is $n_{0_{2}}$ and is calculated from the mass of the sample, $m_{s}$, and its composition. The reference temperature for the reaction is $t(\mathrm{av})$ and is the midtemperature between the initial and final temperatures of the reaction. The quantities $\Delta t$ (corr) and $\Delta t_{c}$ are the correction to the temperature rise and the corrected temperature rise respectively. The quantity $q$ (reaction) is the energy produced by reaction of $n_{0_{2}}$ moles of oxygen at $t(\mathrm{av})$. To calculate $q$ (reaction) from $n_{0_{2}}$ the value $571.28 \mathrm{~kJ}$ $\mathrm{mol}^{-1}$ was used for the heat of reaction of oxygen with hydrogen to form liquid water at $304 \mathrm{~K}$ [5, 14].

The heat of ignition is $q$ (ign) and was based on the rate of ignition-energy generation measured earlier [8]. Other corrections are: $q($ temp), the amount of heat required to raise the temperature of the reacting gases from room temperature to $t(\mathrm{av}) ; q^{\prime}$ (vap), the heat of condensation of the water vapor carried by the hydrogen which is consumed by the reaction; $q^{\prime \prime}(\mathrm{vap})$, the heat of vaporation of water by the helium which is introduced to transfer the oxidizer completely into the reaction vessel. The sum of the corrections (total), is applied to $q$ (reaction) to obtain $q(\mathrm{obs})$. The observed energy equivalent, $E(\mathrm{obs})$, is the ratio of $q(\mathrm{obs})$ to $\Delta t_{c}$. A small correction for the amount of water formed at $t$ (ave), $\Delta e$, is added to the $E$ (obs) to yield the energy equivalent of the standard calorimeter, $E$ (calorim).

The standard calorimeter for the calibration and combustion experiments consisted of the calorimeter can with stirrer and lid, the calorimeter heater, the reaction vessel with $100 \mathrm{~cm}^{3}$ of water in each solution vessel, a small neoprene plug used to close the opening around the outlet tube of the reaction vessel, the immersed portion of the thermometer, and a PTFE ring for sealing the thermometer opening. The average $E$ (calorim) is $21949.1 \mathrm{~J} \mathrm{~K}^{-1}$ with a standard deviation of the mean of $4.4 \mathrm{~J} \mathrm{~K}^{-1}$.

The 0.02 percent standard deviation of the mean is larger than usually observed for calibrations in this laboratory. A more precise calibration may possibly be obtained when the amount of reaction is based on the amount of water formed, because any unreacted oxygen would then be accounted for. 
TABLE 5. The calibration of the calorimeter

$\mathrm{H}_{2}(\mathrm{~g})+1 / 2 \mathrm{O}_{2}(\mathrm{~g}) \rightarrow \mathrm{H}_{2} \mathrm{O}(\mathrm{l})$

\begin{tabular}{|c|c|c|c|c|c|c|}
\hline Expt. No. & 1 & 2 & 3 & 4 & 5 & 6 \\
\hline \multicolumn{7}{|c|}{ a. Heat and reactant measurements } \\
\hline 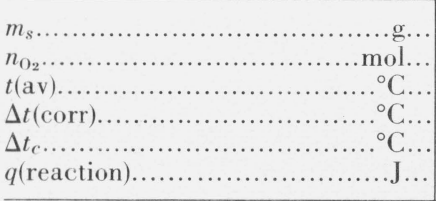 & $\begin{array}{l}2.8449 \\
0.088895 \\
30.42 \\
0.07265 \\
2.32293 \\
50783.9\end{array}$ & $\begin{array}{l}2.7814 \\
0.086911 \\
30.42 \\
0.05807 \\
2.26971 \\
49650.5\end{array}$ & $\begin{array}{l}2.8186 \\
0.088073 \\
30.41 \\
0.06472 \\
2.30022 \\
50314.3\end{array}$ & $\begin{array}{l}2.8405 \\
0.088757 \\
30.41 \\
0.06297 \\
2.31573 \\
50705.1\end{array}$ & $\begin{array}{l}2.8259 \\
0.088301 \\
30.41 \\
0.06721 \\
2.30197 \\
50444.6\end{array}$ & $\begin{array}{l}2.7795 \\
0.086851 \\
30.43 \\
0.05849 \\
2.26562 \\
49616.2\end{array}$ \\
\hline \multicolumn{7}{|c|}{ b. Corrections to the heat data } \\
\hline 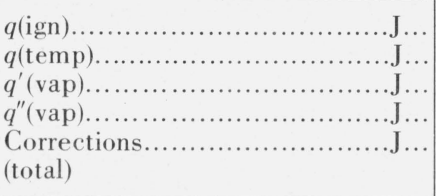 & $\begin{array}{r}24.9 \\
-18.7 \\
253.3 \\
-50.1 \\
209.4\end{array}$ & $\begin{array}{r}36.7 \\
-30.3 \\
228.3 \\
-91.6 \\
143.1\end{array}$ & $\begin{array}{r}22.7 \\
-23.0 \\
242.1 \\
-47.4 \\
194.4\end{array}$ & $\begin{array}{r}22.7 \\
-30.8 \\
233.0 \\
-88.2 \\
136.7\end{array}$ & $\begin{array}{r}24.5 \\
-40.7 \\
218.9 \\
-69.4 \\
133.3\end{array}$ & $\begin{array}{r}26.7 \\
-38.0 \\
215.1 \\
-69.2 \\
134.6\end{array}$ \\
\hline \multicolumn{7}{|c|}{ c. Energy equivalent of the calorimeter } \\
\hline 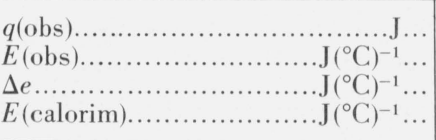 & $\begin{array}{r}50993.3 \\
21952.1 \\
6.7 \\
21945.4\end{array}$ & $\begin{array}{r}49793.6 \\
21938.3 \\
6.5 \\
21931.8\end{array}$ & $\begin{array}{r}50508.1 \\
21958.2 \\
6.6 \\
21951.6\end{array}$ & $\begin{array}{r}50841.8 \\
21955.0 \\
6.7 \\
21948.3\end{array}$ & $\begin{array}{r}50577.9 \\
21971.6 \\
6.7 \\
21964.9\end{array}$ & $\begin{array}{r}49750.8 \\
21959.0 \\
6.5 \\
21952.5\end{array}$ \\
\hline
\end{tabular}

\subsection{The $\mathrm{ClF}_{3}-\mathrm{H}_{2}-\mathrm{H}_{2} \mathrm{O}$ Reaction}

The heat data for the $\mathrm{ClF}_{3}-\mathrm{H}_{2}-\mathrm{H}_{2} \mathrm{O}$ reaction are given in table 6 . Most of the symbols have been explained for the $\mathrm{O}_{2}-\mathrm{H}_{2}$ reaction. Here $\Delta e$ is the increase in the energy equivalent caused by the addition of the product acids to the standard calorimeter. $E$ (calorim) of table 5 , corrected by $\Delta e$, yields $E\left(\mathrm{ClF}_{3}\right)$. The heat of reaction of the oxygen impurity in the $\mathrm{CIF}_{3}$ is $q_{\mathrm{O}_{2}}$. The loss of acid due to corrosion of the reaction vessel is corrected by $q$ (corros). In calculating $q$ (corros) it is assumed that the product acids principally react with the Monel to yield nickel (II) chloride and nickel (II) fluoride. Then the overall corrosion reaction becomes:

$$
\mathrm{ClF}_{3}(\mathrm{~g})+2 \mathrm{Ni}(\mathrm{c}) \rightarrow 1 / 2 \mathrm{NiCl}_{2}(\mathrm{c})+3 / 2 \mathrm{NiF}_{2}(\mathrm{c})
$$

for which $\Delta H$ was taken as $-964.8 \mathrm{~kJ}\left(\mathrm{~mol} \mathrm{ClF}_{3}\right)^{-1}$ based on literature values [5] for the heats of formation of $\mathrm{NiCl}_{2}$ and $\mathrm{NiF}_{2}$ and preliminary results of these experiments for $\mathrm{ClF}_{3}$.

TABLE 6. The $\mathrm{ClF}_{3}-\mathrm{H}_{2}-\mathrm{H}_{2} \mathrm{O}$ reaction

\begin{tabular}{|c|c|c|c|c|c|c|}
\hline Expt. No. & 1 & $2^{a}$ & 3 & 4 & 5 & 6 \\
\hline \multicolumn{7}{|c|}{ a. Heat measurements } \\
\hline ..............g.. & 5.5074 & 5.3577 & 5.1142 & 4.4999 & 5.2142 & 4.9769 \\
\hline 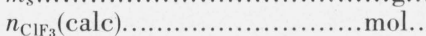 & 0.0594656 & 0.0578492 & 0.0552201 & 0.0485872 & 0.0562998 & 0.0537376 \\
\hline 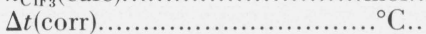 & .05725 & .06031 & .05414 & .05426 & .05437 & .05955 \\
\hline 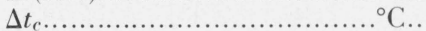 & 2.61907 & 2.53343 & 2.42975 & 2.14235 & 2.48202 & 2.36713 \\
\hline 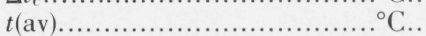 & 30.64 & 30.67 & 30.73 & 30.88 & 30.69 & 30.76 \\
\hline 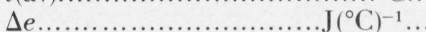 & 3.4 & 3.3 & 3.1 & 2.8 & 3.2 & 3.1 \\
\hline$E\left(\mathrm{ClF}_{3}\right) \ldots \ldots \ldots \ldots \ldots \ldots \ldots \ldots \ldots \ldots \ldots \ldots \ldots$ & 21952.5 & 21952.4 & 21952.2 & 21951.9 & 21952.3 & 21952.2 \\
\hline 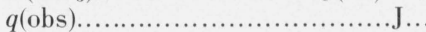 & 57495.1 & 55614.9 & 53338.4 & 47028.7 & 54486.0 & 51963.7 \\
\hline
\end{tabular}

b. Corrections to the heat measurements

\begin{tabular}{|c|c|c|c|c|c|c|}
\hline 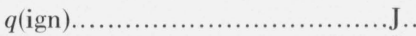 & 56.0 & 41.4 & 36.3 & 38.4 & 33.3 & 42.8 \\
\hline$q($ temp $) \ldots \ldots \ldots \ldots \ldots \ldots$ & -38.3 & -40.1 & -34.9 & -33.7 & -35.6 & -34.6 \\
\hline$q^{\prime}(\operatorname{vap}) \ldots \ldots \ldots \ldots \ldots \ldots$ & 147.1 & 143.0 & 141.1 & 124.4 & 144.2 & 137.4 \\
\hline$q^{\prime \prime}(\operatorname{vap}) \ldots \ldots \ldots \ldots \ldots$ & -80.2 & -129.2 & -96.5 & -99.1 & -169.5 & -146.4 \\
\hline$q_{\mathrm{O}_{2}} \ldots \ldots \ldots \ldots \ldots \ldots \ldots \ldots \ldots \ldots \ldots \ldots$ & 148.5 & 142.2 & 137.1 & 120.0 & 137.1 & 131.4 \\
\hline Corrections (total) $\ldots \ldots \ldots \ldots$ & 233.1 & 157.3 & 183.1 & 150.0 & 109.5 & 130.6 \\
\hline 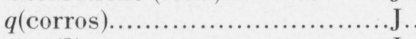 & 1263.9 & 1638.2 & 1310.2 & 991.8 & 412.9 & 1109.5 \\
\hline$q_{\mathrm{ClF}_{3}}(1) \ldots \ldots \ldots \ldots \ldots \ldots \ldots \ldots \ldots \ldots \ldots \ldots \ldots \ldots \ldots \ldots$ & 57262.0 & 55457.6 & 53155.3 & 46878.7 & 54376.5 & 51833.1 \\
\hline$q_{\mathrm{CIF}_{3}}(2) \ldots \ldots \ldots \ldots \ldots \ldots \ldots \ldots \ldots \ldots \ldots \ldots \ldots \ldots \ldots \ldots \ldots$ & 55998.1 & 53819.4 & 51845.1 & 45886.9 & 53963.6 & 50723.6 \\
\hline 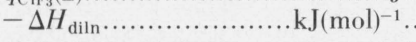 & 0.07 & 0.01 & -0.02 & -0.14 & 0.01 & -0.05 \\
\hline
\end{tabular}

${ }^{a}$ Not used in the final results. 
Correction (total) is the sum of the corrections excluding $q$ (corros). The heat of reaction of the chlorine trifluoride is $q_{\mathrm{ClF}_{3}}(1)$, and is $q(\mathrm{obs})$ minus corrections (total). The quantity $q_{\mathrm{ClF}_{3}}(2)$ is equal to $q_{\mathrm{ClF}_{3}}(1)$ minus the correction for corrosion, $q$ (corros). The final item of the table, $-\Delta H_{\text {diln }}$ is the energy correction for the adjustment of the acid-water ratios (table 3 ) to $\left[\mathrm{HCl} \cdot 100 \mathrm{H}_{2} \mathrm{O}\right](\mathrm{l})$ and $\left[3 \mathrm{HF} \cdot 100 \mathrm{H}_{2} \mathrm{O}\right](\mathrm{l})$. Note that this is a molar energy and is applied after conversion of the energy quantities to a molar basis.

The data for the enthalpy of reaction of chlorine trifluoride are tabulated in table 7 . The reaction to which $\Delta H(1), \Delta H(2)$, and $\Delta H(3)$ apply is shown at the beginning of the table. The heats of reaction are:

TABLE 7. The enthalpy change of the $\mathrm{CIF}_{3}-\mathrm{H}_{2}-\mathrm{H}_{2} \mathrm{O}$ reaction. $303.5 \mathrm{~K}$

$\mathrm{ClF}_{3}(\mathrm{~g})+2 \mathrm{H}_{2}(\mathrm{~g})+100 \mathrm{H}_{2} \mathrm{O}(\mathrm{l}) \rightarrow\left[\mathrm{HCl} \cdot 3 \mathrm{HF} \cdot 100 \mathrm{H}_{2} \mathrm{O}\right](\mathrm{l})$

\begin{tabular}{|c|c|c|c|}
\hline Expt. No. & $\begin{array}{c}-\Delta H(1)^{b} \\
\mathrm{~kJ}\left(\text { mol ClF }_{3}\right)^{-1} \\
(\text { mass })\end{array}$ & $\begin{array}{c}-\Delta H(2)^{b} \\
\left.\mathrm{~kJ}(\text { mol ClF })_{3}\right)^{-1} \\
(\text { titration })\end{array}$ & $\begin{array}{c}-\Delta H(3)^{c} \\
\mathrm{~kJ}\left(\text { mol } \mathrm{ClF}_{3}\right)^{-1} \\
\quad(\text { titration })\end{array}$ \\
\hline 1 & 963.01 & 984.71 & 96298 \\
\hline 2 & " 958.67 & " 987.64 & " 958.47 \\
\hline 3 & 96259 & 98686 & 962.53 \\
\hline 4 & 964.70 & 985.53 & 964.68 \\
\hline 5 & 965.86 & 973.24 & 965.85 \\
\hline 6 & 964.51 & 985.61 & 964.52 \\
\hline Average....... & d 964.13 & 983.19 & d 964.11 \\
\hline Standard de- & & & \\
\hline 1 & 0.59 & 2.49 & 0.60 \\
\hline
\end{tabular}

"Not included in the average.

No correction for corrosion has been applied.

Correction for corrosion has been applied.

${ }^{d}$ The close agreement of the average values of $\Delta H(1)$ and $\Delta H(3)$ is fortuitous and is due to the fact that the enthalpy change of the assumed corrosion reaction (Sec. 4.2) is extremely close to the enthalpy change of the reaction under study.
$\Delta H(1)=q_{\mathrm{ClF}_{3}}(1) / n_{\mathrm{ClF}_{3}}($ mass $)-\Delta H_{\mathrm{diln}} ; \Delta H(2)=$ $q_{\mathrm{ClF}_{3}}(1) / n_{\mathrm{ClF}_{3}}$ (titration) $-\Delta H_{\mathrm{dil}}$; and $\Delta H(3)=q_{\mathrm{ClF}_{3}}(2) / n_{\mathrm{ClF}_{3}}$ (titration) $-\Delta H_{\mathrm{diln}} \cdot \Delta H(1)$ is the heat of reaction of chlorine trifluoride introduced into the reaction, assuming no loss of the product acid due to corrosion. In calculating $\Delta H(2)$, we have imagined no corrosion, but used the product acid recovered as the basis of the amount of reaction. $\Delta H(3)$ is corrected for corrosion and is based on the observed amount of product acid. These three are the modes of calculation for which some justification could be presented.

In an earlier study on the heat of formation of oxygen difluoride, we made similar comparisons of the heat of reaction computed by these three methods of treating the heat data. From that study and also from the earlier discussion on the completeness of this reaction, there are clear indications that $\Delta H(3)$ is the most valid treatment of the data. Therefore, we take the heat of this reaction to be 964.11 (with a standard deviation of the mean of $\left.0.60 \mathrm{~kJ}\left(\mathrm{~mol} \mathrm{ClF}_{3}\right)^{-1}\right)$.

\subsection{The Enthalpy Changes of the $\mathrm{Cl}_{2}-\mathrm{H}_{2}-\mathrm{H}_{2} \mathrm{O}$ and $\mathrm{Cl}_{2}-\mathrm{H}_{2}-\mathrm{HF}_{\mathrm{aq}}$ Reactions}

The heat data for the $\mathrm{Cl}_{2}-\mathrm{H}_{2}-\mathrm{H}_{2} \mathrm{O}$ and $\mathrm{Cl}_{2}-\mathrm{H}_{2}-\mathrm{HF}_{\text {aq }}$ reactions are given in tables 8 and 9. The symbols have the same meaning and the calculations were treated in the same way as those for the $\mathrm{ClF}_{3}-\mathrm{H}_{2}-\mathrm{H}_{2} \mathrm{O}$ reaction. The term $\Delta e$ is the correction to the energy equivalent for the $\mathrm{HCl}$ formed and $q_{0_{2}}$ corrects for the heat of reaction of the oxygen impurity. The quantity $q$ (corros) is the heat of the reaction of chlorine with nickel and is based on the following reaction:

$$
\begin{gathered}
\mathrm{Cl}_{2}(\mathrm{~g})+\mathrm{Ni}(\mathrm{c}) \rightarrow \mathrm{NiCl}_{2}(\mathrm{c}) \\
\Delta H=-305.33 \mathrm{~kJ}(\mathrm{~mol} \mathrm{Cl})^{-1}[5]
\end{gathered}
$$

TABle 8. The $\mathrm{Cl}_{2}-\mathrm{H}_{2}-\mathrm{H}_{2} \mathrm{O}$ and $\mathrm{Cl}_{2}-\mathrm{H}_{2}-\mathrm{HF}_{\text {aq }}$ reactions.

\begin{tabular}{|c|c|c|c|c|c|c|c|c|c|}
\hline & \multicolumn{4}{|c|}{$\mathrm{Cl}_{2}-\mathrm{H}_{2}-\mathrm{H}_{2} \mathrm{O}(\mathrm{l})$} & \multicolumn{5}{|c|}{$\mathrm{Cl}_{2}-\mathrm{H}_{2}-\mathrm{HF}_{\mathrm{aq}}$} \\
\hline \multicolumn{10}{|c|}{ a. Heat measurements } \\
\hline Expt. No. & 1 & 2 & 3 & 4 & 1 & 2 & 3 & 4 & 5 \\
\hline$m_{s} \ldots \ldots$. & 9.6607 & 6.7661 & 6.6417 & 7.6865 & 2.1408 & 2.5748 & 4.4517 & 2.2925 & 1.5869 \\
\hline$\Delta t($ corr $) ..$ & 0.10842 & 0.09534 & 0.08107 & 0.04724 & 0.02462 & 0.02384 & 0.03123 & 0.03243 & 0.02717 \\
\hline$\Delta t_{c} \ldots \ldots \ldots$ & 2.04072 & 1.43670 & 1.41563 & 1.63739 & 0.45570 & 0.54595 & 0.95003 & 0.48592 & 0.33382 \\
\hline 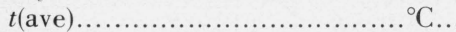 & 30.69 & 30.45 & 30.49 & 30.92 & 31.33 & 31.39 & 31.21 & 31.17 & 31.33 \\
\hline 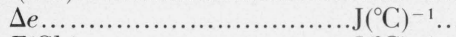 & 3.9 & 2.7 & 2.7 & 3.1 & -1.9 & -7.9 & -7.1 & -7.7 & -7.9 \\
\hline 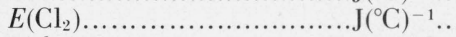 & 21953.0 & 21951.8 & 21951.8 & 21952.2 & 21947.2 & 21941.2 & 21942.0 & 21941.4 & 21941.2 \\
\hline 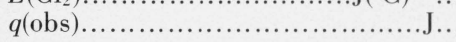 & 44799.9 & 31538.2 & 31075.6 & 35944.3 & 10001.3 & 11978.8 & 20845.6 & 10661.8 & 7324.4 \\
\hline
\end{tabular}

$303.5 \mathrm{~K}$

\begin{tabular}{|c|c|c|c|c|c|c|c|c|c|}
\hline 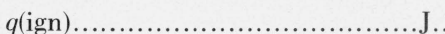 & 25.3 & 49.0 & 36.5 & 28.4 & 28.4 & 17.8 & 21.4 & 28.0 & 15.1 \\
\hline 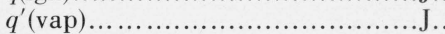 & 173.8 & 122.2 & 123.1 & 132.4 & 37.1 & 48.0 & 77.3 & 41.0 & 27.4 \\
\hline 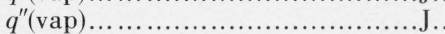 & -104.8 & -100.1 & -125.3 & -76.9 & -88.3 & -113.5 & -127.1 & -100.8 & -94.7 \\
\hline 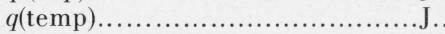 & -46.9 & -31.3 & -26.4 & -40.2 & -12.1 & -14.2 & -23.8 & -12.1 & -8.8 \\
\hline$q_{0_{2}} \ldots \ldots \ldots \ldots \ldots \ldots \ldots \ldots \ldots \ldots \ldots \ldots \ldots \ldots \ldots \ldots \ldots \ldots \ldots$ & 28.6 & 22.9 & 22.9 & 22.9 & 5.7 & 11.4 & 11.4 & 5.7 & 5.7 \\
\hline Corrections (total) .................... J. & 76.0 & 62.7 & 30.8 & 66.6 & -29.2 & -50.5 & -40.8 & -38.2 & -55.3 \\
\hline 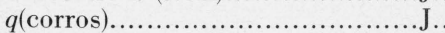 & 387.8 & 26.0 & 27.5 & 59.5 & 22.9 & 12.2 & 33.6 & 76.3 & \\
\hline$q_{\mathrm{Cl}_{2}}(1) \ldots \ldots \ldots \ldots \ldots \ldots \ldots \ldots \ldots \ldots \ldots \ldots \ldots \ldots \ldots \ldots$ & 44723.9 & 31475.5 & 31044.8 & 35877.7 & 10030.5 & 12029.3 & 20886.4 & 10700.0 & 7379.7 \\
\hline$q_{\mathrm{Cl}_{2}}(2) \ldots \ldots \ldots \ldots \ldots \ldots \ldots \ldots \ldots \ldots \ldots \ldots \ldots$ & 44336.1 & 31449.5 & 31017.3 & 35818.2 & 10007.6 & 12017.1 & 20852.8 & 10623.7 & 7379.7 \\
\hline$-\Delta H_{\mathrm{diln}} \ldots \ldots \ldots \ldots \ldots \ldots \ldots \ldots \ldots \ldots \ldots(\mathrm{mol})^{-1}$ & 2.08 & 1.26 & 1.26 & 1.76 & 0.12 & 0.21 & 0.79 & 0.08 & -0.08 \\
\hline
\end{tabular}

b. Corrections to the heat measurements 
TABLE 9. The enthalpy changes of the $\mathrm{Cl}_{2}-\mathrm{H}_{2}-\mathrm{H}_{2} \mathrm{O}$ and $\mathrm{Cl}_{2}-\mathrm{H}_{2}-\mathrm{HF}_{\mathrm{aq}}$ reactions

$303.5 \mathrm{~K}$

I. $1 / 2 \mathrm{Cl}_{2}(\mathrm{~g})+\mathrm{l} / 2 \mathrm{H}_{2}(\mathrm{~g})+100 \mathrm{H}_{2} \mathrm{O}(\mathrm{l}) \rightarrow\left[\mathrm{HCl}: 100 \mathrm{H}_{2} 0\right](\mathrm{l})$

II. $1 / 2 \mathrm{Cl}_{2}(\mathrm{~g})+1 / 2 \mathrm{H}_{2}(\mathrm{~g})+\left[3 \mathrm{HF}: 100 \mathrm{H}_{2} \mathrm{O}\right](\mathrm{l})=\left[\mathrm{HCl} \cdot 3 \mathrm{HF} \cdot 100 \mathrm{H}_{2} \mathrm{O}\right](\mathrm{l})$

\begin{tabular}{c|c|c|c}
\hline \hline \multicolumn{4}{|c}{$\mathrm{I}$} \\
\hline & $-\Delta H(1)^{\mathrm{a}}$ & $-\Delta H(2)^{\mathrm{a}}$ & $-\Delta H(3)^{\mathrm{b}}$ \\
\hline Expt. No. & \multicolumn{3}{|c}{$\mathrm{kJ}\left(\mathrm{mol} \mathrm{HCl}_{\mathrm{aq}}\right)^{-1}$} \\
\hline 1 & 166.32 & 167.87 & 166.43 \\
2 & 166.31 & 166.46 & 166.32 \\
3 & 167.10 & 167.26 & 167.11 \\
4 & 167.37 & 167.67 & 167.39 \\
Average........... & 166.78 & 167.32 & 166.81 \\
Standard devia- & \multicolumn{3}{|c}{} \\
tion of the & 0.27 & 0.32 & 0.27 \\
mean............. & 0.27 \\
\hline
\end{tabular}

II

\begin{tabular}{c|c|c|c}
\hline 1 & 166.35 & 166.77 & 166.39 \\
2 & 165.95 & 166.13 & 165.96 \\
3 & 167.24 & 167.53 & 167.27 \\
4 & 165.56 & 166.85 & 165.66 \\
5 & 165.98 & 165.50 & 165.50 \\
Average............ & 166.22 & 166.56 & 166.16 \\
$\begin{array}{c}\text { Standard devia- } \\
\text { tion of the }\end{array}$ & & & \\
mean.............. & 0.32 & 0.34 & 0.31 \\
\hline
\end{tabular}

"No correction for corrosion has been applied.

${ }^{b}$ Correction for corrosion has been applied.

\section{Derivation of $\Delta \boldsymbol{H}_{f}\left[\mathrm{ClF}_{3}\right]$}

\subsection{Discussion of Errors in the $\mathrm{ClF}_{3}-\mathrm{H}_{2}-\mathrm{H}_{2} \mathrm{O}$, $\mathrm{Cl}_{2}-\mathrm{H}_{2}-\mathrm{H}_{2} \mathrm{O}$, and $\mathrm{Cl}_{2}-\mathrm{H}_{2}-\mathrm{HF}_{\mathrm{aq}}$ Reactions}

The total uncertainty in the heats of reaction is calculated by combining the random errors with the total systematic errors. The error analysis is summarized in table 10. For each system the total random error is obtained by combining the standard deviations of the means for the calibrations $\left(\sigma_{c}\right)$ and reaction $\left(\sigma_{r}\right)$. We shall refer to this error $\left(2 \sqrt{\sigma_{r}^{2}+\sigma_{c}^{2}}\right)$ as the imprecision [18].
The systematic error in the calibration is independent of the remaining systematic chemical errors and depends on the accuracy of the $\mathrm{O}_{2}-\mathrm{H}_{2}$ reaction [15]. The systematic error in the $\mathrm{ClF}_{3}$ measurements caused by uncertainty in the analysis of the sample is estimated to be 0.2 percent. This estimate takes into the account the possible presence of $\mathrm{Cl}-\mathrm{O}-\mathrm{F}$ compounds in the sample which could not be analyzed for by the methods available. An analysis of the enthalpy of reaction versus the percent correction for corrosion for the $\mathrm{ClF}_{3}-\mathrm{H}_{2}-\mathrm{H}_{2} \mathrm{O}$ experiments suggests a certain amount of irrelevance or lack of appropriateness in the correction for corrosion. A plot of $\Delta H(2)$ and $\Delta H(3)$ versus percent correction for corrosion (100 $q$ (cor$\operatorname{ros}) / q_{\mathrm{CIF}_{3}}(2)$ ) is given in figure 3 (Lines I and II, respectively). The intercepts are the enthalpies of reaction if there is no corrosion and the intercepts agree closely for the two curves. However, the slope for curve II representing the heats of reaction corrected for corrosion, is larger than expected. This causes a comparatively large difference between the intercept 967.30 and the average $-\Delta H(3), 964.11 \mathrm{~kJ}\left(\mathrm{~mol} \mathrm{ClF}_{3}^{-1}\right)$ given in table 7 . The difference in these values conceivably could be caused by an error in the data for one of the experiments (experiment 5). In plotting the data, an error in this point could cause a sizable slope of the line. A modest error can cause a large deviation in the intercept. The residual slope is the reason for assuming the $q$ (corros) to be somewhat irrelevant and assigning the 0.33 percent systematic error for irrelevance of the corrosion correction. The average value rather than the intercept is adopted as the valid value for $\Delta H(3)$. The slope of the adjusted data, when compared with similar data for $\mathrm{OF}_{2}$ and $\mathrm{F}_{2}[8]$, can also be interpreted as a more pronounced effect than had previously been observed, but in the same direction. If taken rigorously it is apparently the result of an over-correction for the corrosion. This could occur, for instance, if the energy of the corrosion reaction is assigned too great a value, or if the difference in $n_{\mathrm{ClF}_{3}}$ (mass) and $n_{\mathrm{ClF}_{3}}$ (titration) is exaggerated by loss of material from the calorimeter. While we consider these to be real possibilities, we consider their application to the data to be too speculative to present here.

TABLE 10. Summary of errors

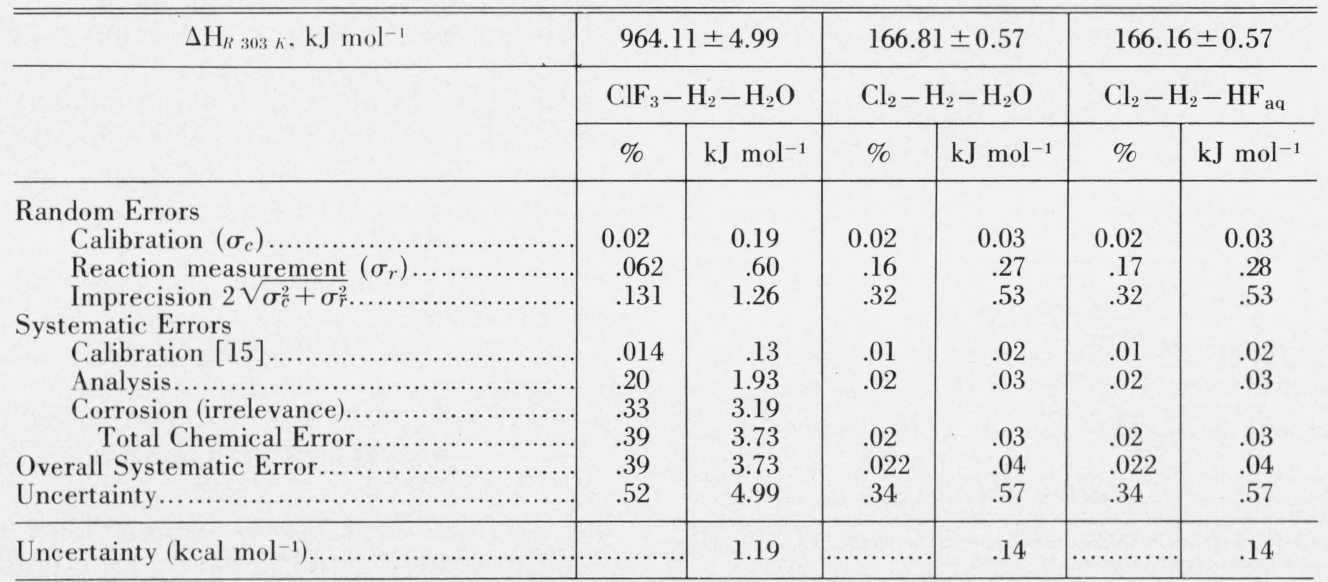


A statistical analysis of curves I and II leads to the 95 percent confidence limits for intercept and slope shown in figure 3 . At the 95 percent confidence limit the slope of curve II does not differ from zero, and this is consistent with our selection of the mean value as the best value of $\Delta H(3)$. The mean value is also within the 95 percent confidence limits of the intercept. The possible systematic error due to the corrosion correction is taken to be the difference between the mean value and the intercept, $3.19 \mathrm{~kJ} \mathrm{~mol}^{-1}$.

The chemical errors are the analysis and corrosion errors. They are independent and are therefore combined as the square root of the sum of the squares of the individual errors. The overall systematic error is added to the imprecision to obtain the total uncertainty.

\subsection{The Heat of Formation of $\mathrm{ClF}_{3}$ at $298.15 \mathrm{~K}$}

The heat of formation of chlorine trifluoride is based on the reactions and heat data given in table 11 . The heats of reactions (2) and (3) were presented in tables 7 and 9 and the uncertainties were derived above. The enthalpy of reaction (4) was taken from [8], and of reaction (5) from [5].

The heat of formation of $\mathrm{ClF}_{3}$ becomes $164.65 \pm 5.14$ $\mathrm{kJ} \mathrm{mol}^{-1}$ at $303.5 \mathrm{~K}$. This value remains unchanged when adjusted to $298.15 \mathrm{~K}$. The estimated uncertainty is the square root of the sum of the squares of the errors for the heats of the reactions including twice the standard deviation of the mean of the experiments.

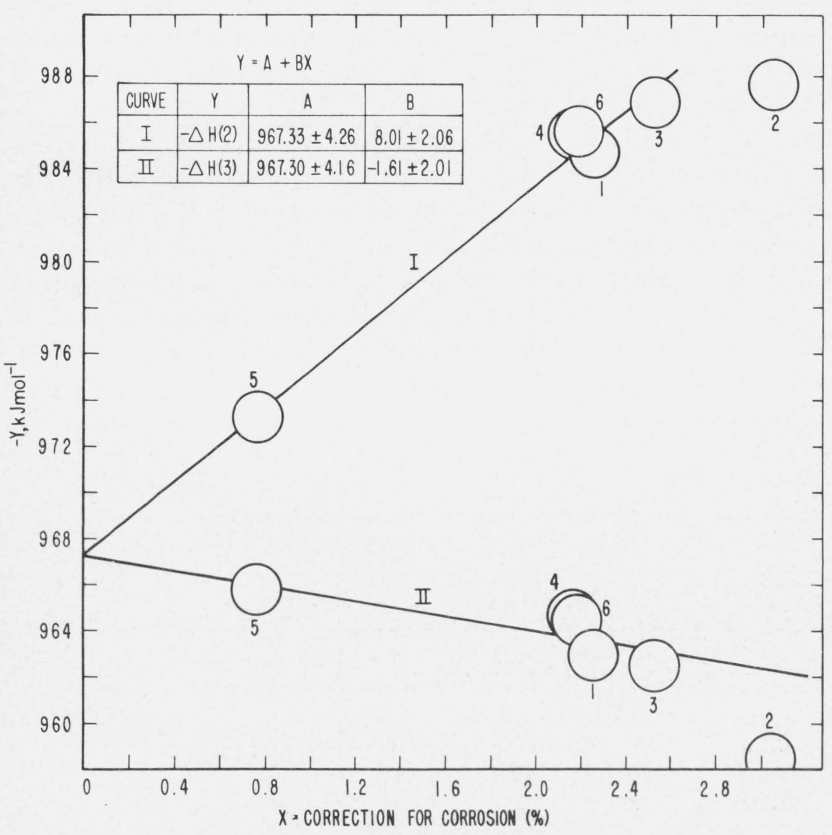

FiguRE 3. Variation of the molar enthalpy of reaction for the $\mathrm{ClF}_{3}-\mathrm{H}_{2}-\mathrm{H}_{2} \mathrm{O}$ reaction with correction for corrosion.

Values of $\mathrm{Y},-\Delta H(2)$ and $-\Delta H(3)$, are taken from table 7 . Values of $\mathrm{X}$ are $100 \times q($ cor ros) $/ q_{\mathrm{ClF}_{3}}(2)$, from table 6 .

Lines I and II were derived by least squares analysis of the data. Data points are identified by the experiment number. Data point 2 was not used in the derivation of the equations. Constants for the equations are given in the box. Uncertainties listed are 95 percent confidence limits based on 5 dat a points and 3 degrees of freedom.
TABLE 11. The heat of formation of $\mathrm{ClF}_{3}(\mathrm{~g})$

$303.5 \mathrm{~K}$

\begin{tabular}{|c|c|}
\hline & $\begin{array}{l}\Delta H \text { and Total Uncertainty }{ }^{a} \\
\qquad \mathrm{~kJ} \mathrm{~mol}^{-1}\end{array}$ \\
\hline 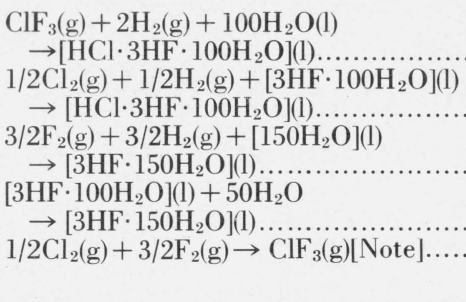 & $\begin{array}{c}-964.11 \pm 4.99 \\
-166.16 \pm 0.57 \\
-962.64 \pm 1.0 \\
-0.04 \\
-164.65 \pm .14 \quad(3) \\
\left(-39.35 \pm 1.23 \mathrm{kcal} \mathrm{mol}^{-1}\right)\end{array}$ \\
\hline
\end{tabular}

[Note] Reaction 1 is the sum of Reaction $(3+4-5-2)$.

${ }^{a}$ Estimated 95 percent confidence limits.

It, therefore, indicates approximately the 95 percent confidence limits of the value.

\subsection{The Mixed Acid Solutions, $\mathrm{HCl} \cdot 100 \mathrm{H}_{2} \mathrm{O}$ and $\mathrm{HCl} \cdot 3 \mathrm{HF} \cdot 100 \mathrm{H}_{2} \mathrm{O}$}

It is interesting to compare the difference between the heats of reaction of $\mathrm{Cl}_{2}$ and $\mathrm{H}_{2}$ to form [ $\mathrm{HCl} \cdot 100 \mathrm{H}_{2} \mathrm{O}$ ] and $\left[\mathrm{HCl} \cdot 3 \mathrm{HF} \cdot 100 \mathrm{H}_{2} \mathrm{O}\right]$. The values are $166.81 \pm 0.57$ $\mathrm{kJ}(\mathrm{mol} \mathrm{HCl})^{-1}$ and $166.16 \pm 0.57 \mathrm{~kJ}(\mathrm{~mol} \mathrm{HCl})^{-1}$. When the uncertainties are applied, the two values overlap. This indicates that the $\mathrm{HF}$ present has little thermal effect on the solution of $\mathrm{HCl}$ for a $1: 3$ ratio of $\mathrm{HCl}$ to $\mathrm{HF}$.

\subsection{The Heat of Formation of $\left[\mathrm{HCl} \cdot 100 \mathrm{H}_{2} \mathrm{O}\right](\mathrm{I})$ at 298.15 K}

A definitive study of the heat of formation of [ $\mathrm{HCl}$ : $\left.100 \mathrm{H}_{2} \mathrm{O}\right]$ was not the main purpose of this study. However, it is of interest to compare the results with the selected data in the literature as an indication of the overall validity of the methods used. For $\left[\mathrm{HCl} \cdot 100 \mathrm{H}_{2} \mathrm{O}\right]$, a value of $-165.92 \mathrm{~kJ} \mathrm{~mol}^{-1}\left(39.657 \mathrm{kcal} \mathrm{mol}^{-1}\right)$ is reported [5]. This value is based on the earlier study on the $\mathrm{Cl}_{2}-\mathrm{H}_{2}$ system performed by Rossini [15], and the enthalpy of solution data given by Parker [16]. A value of $-166.81 \pm 0.57 \mathrm{~kJ} \mathrm{~mol}^{-1}$ at $303.5 \mathrm{~K}$ is obtained here (Reaction 7). By our reduction to 298.15 using heat capacity data for $\mathrm{H}_{2}$ and $\mathrm{Cl}_{2}$ from [5] and for $\mathrm{HCl} \cdot 100 \mathrm{H}_{2} \mathrm{O}$ from [16] we calculate $\Delta H_{298.15}^{\circ}=$ $-166.02 \mathrm{~kJ} \mathrm{~mol}^{-1} \pm 0.57 \mathrm{~kJ} \mathrm{~mol}^{-1}$. The difference from the selected value is well within the uncertainty assigned to the measurements. An important difference between our study and Rossini's is our use of a metal reaction vessel, compared to the Pyrex burner in Rossini's investigation. Also, our study leads directly to the formation of $\left[\mathrm{HCl} \cdot 100 \mathrm{H}_{2} \mathrm{O}\right]$ from $\mathrm{Cl}_{2}, \mathrm{H}_{2}$, and liquid water.

\subsection{The $\mathrm{Cl}-\mathrm{F}$ Bond Energy}

The average $\mathrm{Cl}-\mathrm{F}$ bond energy in $\mathrm{ClF}_{3}$ is derived to be $38.25 \mathrm{kcal} \mathrm{mol}^{-1}$, on the basis of the enthalpy of for- 
mation of chlorine trifiuoride presented in this paper, $\Delta H_{f}^{\circ}[\mathrm{Cl}(\mathrm{g})]=29.082 \mathrm{kcal} \mathrm{mol}^{-1}[5]$ and the recent energy of dissociation of fluorine, $\Delta H_{f}^{\circ}[2 \mathrm{~F}(\mathrm{~g})]=30.9 \mathrm{kcal}$ $\mathrm{mol}^{-1}$, reported by Dibeler, Walker, and McCulloh [17].

$$
\begin{gathered}
1 / 3 \mathrm{ClF}_{3}(\mathrm{~g}) \rightarrow 1 / 3 \mathrm{Cl}+\mathrm{F} \\
\frac{-39.35}{3} \quad \frac{29.082}{3} \quad 15.45 \\
E(\mathrm{Cl}-\mathrm{F})=38.26 \mathrm{kcal} \mathrm{mol}^{-1}\left(160.1 \mathrm{~kJ} \mathrm{~mol}^{-1}\right)
\end{gathered}
$$

In a later report on the enthalpy of formation of chlorine pentafluoride, which was also determined in this laboratory, it will be possible to report $E(\mathrm{Cl}-\mathrm{F})$ bond energies for the sequence, $\mathrm{ClF}^{*}, \mathrm{ClF}_{3}$, and $\mathrm{ClF}_{5}$. Note that the absolute values of these bond energies are strongly dependent on the value selected for the dissociation energy of fluorine.

\section{References}

[1] Schmitz, H., and Schumacher, H. J., Z. Naturforsch. 2a, 362 (col. 1) (1947).

[2] Schäfer, K., and Wicke, H., Z. Elecktrochem. 52, 205 (1948).

[3] von Wartenberg, H., and Riteris, G., Z. anorg. Chem. 258, 356 (1949).

[4] Schmitz, H., and Schumacher, H. J., Z. Naturforsch. 2a, 362 (col. 2) (1947).

[5] Wagman, D. D., Evans, W. H., Halow, I., Parker, V. B., Bailey, S. M., and Schumm, R. H., Selected Values of Chemical Thermodynamic Properties, Part 1. Tables for the First Fifty-three Elements in the Standard Order of Arrangement, Nat. Bur. Stand. (U.S.), Tech. Notes 270-3 and $270-4(1968,1969)$.

[6] JANAF Thermochemical Tables, Dow Chemical Co., Midland, Michigan (PBl68370, Clearinghouse for Federal Scientific and Technical Information, Springfield, Va., August, 1966).

[7] Armstrong, G. T., and Jessup, R. S., J. Res. Nat. Bur. Stand. (U.S.), 64A, (Phys. and Chem.)., No. 1, 49 (Jan.-Feb. 1960).

[8] King, R. C., and Armstrong, G. T., J. Res. Nat. Bur. Stand (U.S.), 72A, (Phys, and Chem.), No. 2, 113 (March-Apr. 1968).

[9] Bigelow, L. A., Chem. Revs. 40, 110 (1947).

[10] Schmitz, H., and Schumacher, H. J., Z. anorg. u. allgem. Chem. 245, 221 (1940).

[11] Shomate, C. H., U.S. Naval Ordnance Laboratory (China Lake, Calif.) private communication (January, 1967).

[12] Cameron, A. E., and Wichers, E., J. Am. Chem. Soc. 84, 4175 (1962).

[13] Osborne, N. S., Stimson, H. F., and Ginnings, D. C., J. Res. NBS 23, 197 (1939).

[14] Rossini, F. D., BS J. Research 6, 1 (1931) RP 259; See also Chapter 4, Experimental Thermochemistry, ed. F. D. Rossini (Interscience Publishers, Inc., New York, N.Y., 1956).

[15] Rossini, F. D., BS J. Research 9, 679 (1932) RP 499.

[16] Parker, V. B., Thermal Properties of Aqueous Uni-univalent Electrolytes, Nat. Stand. Ref. Data Ser., Nat. Bur. Stand. (U.S.), 2, 66 pages (April 1965).

[17] Dibeler, V. H., Walker, J. A., and McCulloh, K. E., J. Chem. Phys. 51, 4230 (1969); 50, 4592 (1969).

[18] Eisenhart, C., J. Res. Nat. Bur. Stand. (U.S.), 67C (Eng. and Instr.), No. 2, 161-187 (Apr.-June 1963).

(Paper 74A6-640) 